\title{
SISTEM INFORMASI UNTUK WISATA DI KUDUS BERBASIS TEKNOLOGI WEB SEMANTIK
}

\author{
Ahmad Ahsana Taqwim ${ }^{1}$, Mukhamad Nurkamid ${ }^{2}$, Rizkysari Meimaharani ${ }^{3}$ \\ ${ }^{1}$ Progam Studi Teknik Informatika, Fakultas Teknik, Universitas Muria Kudus \\ ${ }^{2}$ Progam Studi Teknik Informatika, Fakultas Teknik, Universitas Muria Kudus \\ ${ }^{3}$ Progam Studi Teknik Informatika, Fakultas Teknik, Universitas Muria Kudus \\ Email: ${ }^{1}$ 201751140@std.umk.ac.id, ${ }^{2}$ muhammad.nurkamid@umk.ac.id, ${ }^{3}$ rizkyumk12@gmail.com
}

(Naskah masuk: 05 Oktober 2021, diterima untuk diterbitkan: 06 Desember 2021)

\begin{abstract}
Abstrak
Kudus merupakan kota di Jawa Tengah yang memiliki banyak wisata alam, yang semakin banyak seiring bertambahnya tahun. Akan tetapi tidak semua lokasi wisata di kota Kudus di ketahui oleh wisatawan. Hal ini karena informasi yang beredar masih sedikit dan kurang lengkap. Oleh karena itu menjadi penting adanya sebuah aplikasi yang dapat memberikan informasi yang lebih lengkap dan rinci untuk tempat wisata di kota Kudus. Penelitian ini membahas tentang perancangan teknologi semantik pada pencarian tempat wisata di kota Kudus. Tujuan dari penelitian ini yaitu menerapkan sebuah model sistem pencarian yang lebih efektif dengan menggunakan ontologi sebagai media penyimpanan datanya dan SPARQL sebagai queri untuk menampilkan informasinya. Hasil dari penelitian ini adalah aplikasi sederhana yang menyajikan informasi untuk wisata di kabupaten Kudus berbasis teknologi semantic web yaitu menggunakan pendekatan ontologi sebagai konsuptal untuk menyimpan datanya dan RDF/OWL sebagai format bahasa yang digunakan dilingkungan web untuk distribusi data.
\end{abstract}

Kata kunci: Web Semantik, Ontologi, Wisata.

\section{INFORMATION SYSTEM FOR TRAVEL IN KUDUS BASED SEMANTIC WEB TECHNOLOGY}

\begin{abstract}
Kudus is a city in Central Java that has many natural attractions, which are increasing as the years increase. However, not all tourist sites in the kudus city are known by tourists. This is because the information circulating is still little and less complete. Therefore it becomes important to have an application that can provide more complete and detailed information for tourist attractions in the kudus city. This research discusses the design of semantic technology in the search for tourist attractions in the kudus city. The purpose of this study is to implement a more effective search system application by using ontology as a data storage medium and SPARQL as a queri to display the information. The result of this study is a application of information presentation for tourism in Kudus district based on semantic web technology that uses ontology approach as a consuptal to store its data and RDF/OWL as a language format used in the web environment for data distribution.
\end{abstract}

Keywords: Web Semantics, Ontology, Travel.

\section{PENDAHULUAN}

Kabupaten Kudus sebagai salah satu Kabupaten di Jawa Tengah terletak di antara 4 (empat) kabupaten yaitu di sebelah utara berbatasan dengan Kabupaten Jepara dan Kabupaten Pati, sebelah timur berbatasan dengan Kabupaten Pati, sebelah selatan dengan Kabupaten Grobogan dan Pati serta sebelah barat berbatasan dengan Kabupaten Demak dan Kabupaten Jepara. di kudus terdapat sebuah gunung yaitu gunung muria dengan tinggi 1602 mdpl yang berbatasan dengan kota jepara dan pati. hal ini yang membuat kudus memiliki banyak sekali objek wisata alam. Wisata termasuk salahsatu hal yang dapat mempengaruhi tumbuhnya perekonomian suatu daerah. Dalam hasil regresi, variabel biaya perjalanan, pendapatan dan fasilitas adalah hal-hal yang mempengaruhi terhadap kunjungan wisatawan ke sebuah obyek wisata (Budihatmojo, 2020)

Adapun jenis wisata yang ada di kabupaten Kudus yaitu wisata sejarah, wisata alam dan wisata religi. Dengan banyaknya objek wisata di kabupaten 
Kudus, sering kali ditemukan masalah yaitu para wisatawan yang merasa kesulitan untuk mencari objek wisata yang ingin mereka kunjungi atau saat mencari tempat penginapan dan restoran. Untuk mengatasi masalah tersebut peneliti bermaksud membuat sebuah aplikasi pencarian objek wisata berbasis semantik web, yang dapat menampilkan referensi berupa tempat penginapan dan restoran.

Manfaat dengan adanya aplikasi pencarian tersebut kami berharap dapat memberikan media informasi yang cepat dan tepat kepada masyarakat umum dalam pencarian tempat wisata dan fasilitas umum di kabupaten Kudus. Adapun hasil dari penelitian ini adalah membuat aplikasi untuk informasi wisata di kabupaten Kudus.

\section{PENELITIAN TERKAIT}

Dalam sebuah penilitian dengan judul "Identifikasi Agenda pada Berita Pilpres 2019 Berbasis Ontologi" berhasil membuktikan bahwa ontologi dapat melakukan identifikasi berita online dan mengelompokkan agenda yang terkait. Peran ontologi dalam penelitian ini yaitu sebagai wadah untuk mengumpulkan beberapa istilah yang saling berhubungan dengan topik umum yaitu agenda pemilihan presiden 2019. Berita akan diproses dan mendeteksi istilah yang terkandung serta mengkategorikan agenda yang berhubungan (Ingan et al., 2020).

Dalam sebuah penelitian dengan judul "Representasi Pengetahuan Dalam Semantik Ontologi Pada Domain Kriminalitas Kepolisian Sektor Depok Timur Daerah Istimewa Yogyakarta" telah membuat sebuah format penampilan data dengan memanfaatkan teknologi semantik ontologi melalui aplikasi Protégé. Yang telah terbukti dapat meningkatkan efisiensi dalam pencarian data kriminal, yaitu dengan $98 \%$ dalam ujicoba recall dan precision (Baskoro et al., 2018).

Dalam sebuah penelitian dengan judul "Peran Ontologi dalam Pengembangan Sistem Rekomendasi pada Domain Online Learning" menyajikan penelitian komprehensif rekomendasi berbasis ontologi pada domain online learning. Dalam penelitian tersebut mengungkapkan bahwa ontologi yang dikombinasikan dengan suatu teknik tertentu banyak digunakan untuk online learning karena efektivitasnya. Dari semua motode yang dikombinasikan paling banyak adalah metode Collaborative Filtering (Wulandari, Pahu and Rahayu, 2020).

Dalam suatu penelitian dengan judul "Model Ontologi Varietas Kelapa Sawit Sebagai Dasar Sistem Berbasis Pengetahuan Riset Perkebunan" menerapkan teknologi semantik web untuk menyimpan data tentang kelapa sawit. Berbagai macam informasi jenis kelapa sawit tersimpan dalam bentuk file owl, yang terdiri dari class, property dan ekspresi data. Dalam penelitian ini terbukti bahwa penyimpanan menggunakan ontologi sangatlah efisien, terutama saat pengecekan konsistensi data dan penambahan data baru (Arif Rakhman Hakim, 2019).

\section{METODE PENELITIAN}

Seorang peneliti yang bernama Natalya F.Noy Deborah L dari Universitas Stanford, Amerika serikat mengembangkan sebuah metode ontologi yang disebut Ontology Development 101. Metode Ontology Development 101 memiliki tujuh tahapan antara lain : (Badron et al., 2017)

1. Menentukan domain dan cakupan ontologi

Dalam tahap ini domain dan cakupan dari ontologi tersebut akan didefinisikan. hal ini bisa dikerjakan dengan memahami domain dan cakupan yang mencakup ontologi yang dibangun, untuk apa ontologi difungsikan, dan siapa yang mengfungsikannya.

2. Mempertimbangkan ontologi yang sudah ada

Penggunaan ontologi yang sudah ada diperlukan jika sistem yang akan dibangun membutuhkan koneksi dengan aplikasi lainnya yang sudah dilakukan suatu ontologi. Ontologi tersebut bisa diperluas untuk domain yang akan dibuat. Banyaknya ontologi yang telah tersedia dengan domain dan cakupan yang mirip dapat menjadi pertimbangan untuk menggunakan ontologi tersebut.

3. Enumerasi kata-kata penting dalam ontologi

Langkah berikutnya menentukan daftar kata yang akan dibangun pada ontologi. langkah ini bisa dilakukan dengan memahami kata apa saja yang akan dibahas, kata yang terkait dengan kata tersebut, dan juga properti kata pada istilah tersebut.

4. Mendefinisikan class dan hierarki class

Pada langkah ini class ontologi dan susunan class dalam hierarki superclass-subclass akan ditentukan. Pendekatan yang digunakan untuk menentukan hierarki dari class adalah pendekatan top-down. Pendekatan ini dimulai dari menentukan konsep umum, setelah itu menentukan konsep yang lebih jelas.

5. Mendefinisikan property dari class

Tahap ini dilakukan setelah class dibuat yaitu menentukan property pada class. Untuk membuat sebuah class menjadi bermakna, diperlukan property yang ada dalam sebuah class tersebut. Menentukan property dapat dilakukan dengan menjelaskan nilai pada property.

6. Menentukan Batasan dari property

Batasan (facet) diperlukan dalam pengembangan ontology yang bertujuan agar sebuah property tidak melebar. Batasan property dikelompokkan menjadi dua, yaitu cardinality, digunakan untuk menentukan banyaknya nilai 
yang ada pada setiap property, dan type untuk menentukan tipe data dalam property.

7. Membuat instance

Langkah terakhir yaitu membuat individual dari class atau dengan arti lain membuat instance. Dalam pembuatan individual harus menentukan class dari individual tersebut, dan selanjutnya diisikan beberapa property.

\section{HASIL PEMBAHASAN}

\subsection{Perancangan Ontologi}

Perancangan ontologi adalah tahapan pertama dalam penelitian ini, yaitu dengan menerapkan ontologi yang telah dirancang sebelumnya. penerapan dapat dimuali dengan membuat sebuah class, object property dan data property pada aplikasi Protege dengan extensi file owl. perancangan ontologi dalam penelitian ini di simpan dengan nama periwisata.owl yang isinya seperti yang ada didalam tabel berikut :

Tabel 1. class, subclass, dan objectproperty

\begin{tabular}{ccc}
\hline Class & SubClass & ObjectProperty \\
\hline lokasi & Thing & mempunyai \\
desa & lokasi & terdapat \\
kecamatan & lokasi & \\
wisata & Thing & \\
\hline
\end{tabular}

Tabel 2. data property, domain dan range

\begin{tabular}{ccc}
\hline Data Property & Domain & Range \\
\hline deskrisi & wisata & string \\
jeniswisata & wisata & string \\
namadesa & desa & string \\
namakecamatan & kecamatan & string \\
namawisata & wisata & string \\
\hline
\end{tabular}

\subsection{Implementasi Ontologi}

Nomor Tahap selanjutnya adalah melakukan implementasi konsep ontologi yang sudah dirancang sebelumnya. dalam aplikasi Protege dibuat class dan subclass yang menampilkan semua data lengkap dengan seluruh informasinya. kemudian data tersebut disusun berdasarkan jenis-jenis yang sesuai.

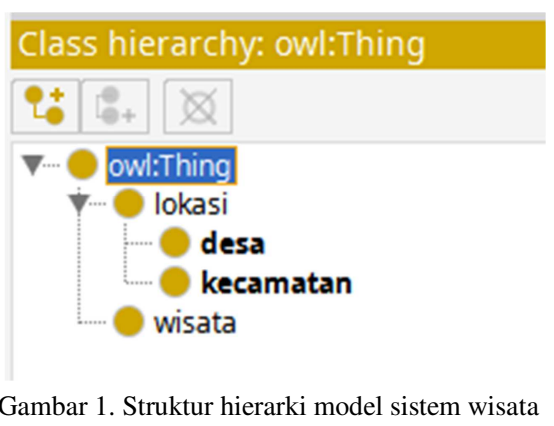

Gambar diatas merupakan penerapan class dari pembuatan ontologi pencarian tempat wisata. Thing merupakan class utama, kemudian diikuti lokasi dan wisata sebagai subclass. didalam class lokasi terdapat subclass yaitu desa dan kecamatan.

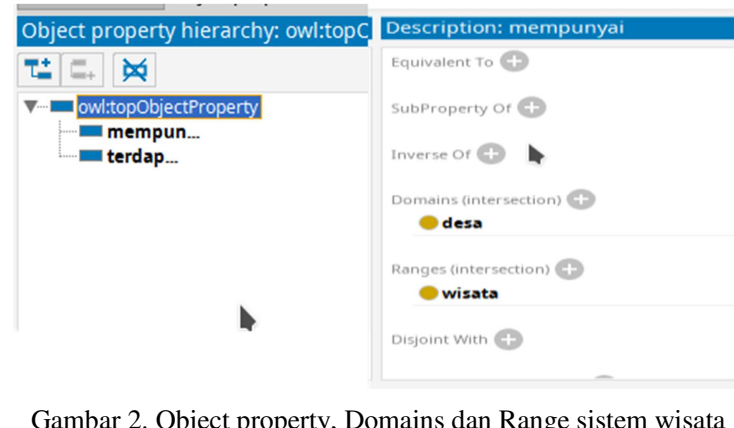

Gambar diatas merupakan penerapan object property yang menghubungkan antara beberapa class yang terdapat pada ontologi sistem pencarian tempat wisata. pada gambar tersebut dapat dilihat bahwa object property "mempunyai" menghubungkan class "desa" class "wisata". dengan demikian dapat dibaca bahwa setiap desa mempunyai sebuah tempat wisata.

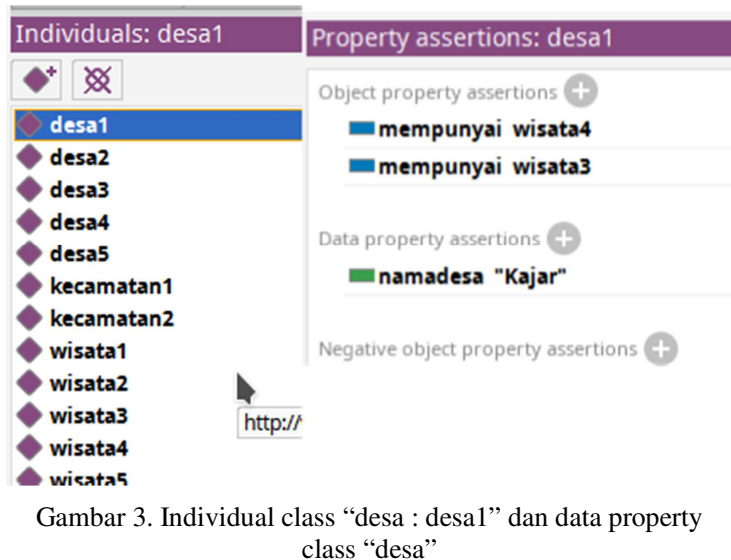

Setiap object pada bagian-bagian class akan diletakkan pada sebuah individual. pada gambar 3 dapat dibaca bahwa ada sebuah individual yang bernama "desa 1" yang terdapat pada class desa. individual tersebut memiliki data property yaitu "namadesa". 


\subsection{Aspek Pengujian Ontologi}

Setelah proses pembangunan ontologi selesai maka perlu adanya sebuah pengujian untuk mengetahui ontologi tersebut sudah sesuai dengan kebutuhan yang diinginkan. beberapa aspek berikut adalah sebagai acuan untuk mengetahui hasil dari ontologi yang telah dibangun, antara lain:

1) Aspek perancangan, aspek ini berfungsi untuk melakukan pengujian terhadap ontologi dengan melihat hasilnya pada aplikasi Protege.

2) Aspek pencarian instance pada model pencarian tempat wisata, aspek ini bisa dilakukan dengan memberi pertanyaan yang sesuai dengan ontologi yang telah dibangun. pada tabel 3 terdapat beberapa pertanyaan untuk menampilkan informasi yang dibutuhkan.

\subsection{Pengujian Ontologi}

Pada tahap ini kita akan melakukan pengujian dengan memberi beberapa pertanyaan. pengujian ini penting untuk pengembangan sebuah ontologi sebelum dapat digunakan.

Tabel 3. Pertanyaan pengujian ontologi pencarian tempat wisata

\begin{tabular}{ll}
\hline No & Pertanyaan \\
\hline 1 & $\begin{array}{l}\text { Tampilkan semua tempat wisata yang } \\
\text { ada di kabupaten kudus }\end{array}$ \\
2 & $\begin{array}{l}\text { Tampilkan wisata alam yang ada di } \\
\text { kudus } \\
3\end{array}$ \\
& $\begin{array}{l}\text { Tampilkan wisata religi yang ada di } \\
\text { kudus } \\
4\end{array}$ \\
5 & Tampilkan wisata di kecamatan kota \\
& montel
\end{tabular}

Pertanyaan-pertanyaan diatas digunakan untuk menguji ontologi, menggunakan queri SPARQL. berikut adalah hasil dari pengujian yang diurutkan berdasarkan perntanyaan tersebut.

1) Tampilkan semua tempat wisata yang ada di kabupaten Kudus.

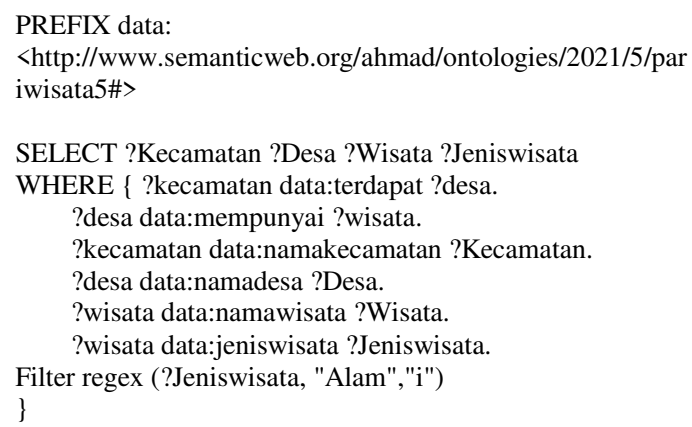

Hasil:

\begin{tabular}{|l|l|l|l|}
\multicolumn{1}{|c|}{ Kecamatan } & \multicolumn{1}{c}{ Desa } & \multicolumn{1}{c}{ Wisata } & \multicolumn{1}{c}{ Jeniswisata } \\
"Kecamatan Kota" & "Wergu wetan" & "Taman Krida/Taman Lampion" & "alam" \\
"Dawe" & "Colo" & "Air Terjun Montel" & "alam" \\
"Dawe" & "Colo" & "Makam Sunan Muria" & "religi" \\
"Kecamatan Kota" & "Kauman" & "Makam Sunan Kudus" & "Religi" \\
"Dawe" & "Kajar" & "Desa Wisata Kandangmas" & "alam" \\
"Dawe" & "Kajar" & "Taman Sardi" & "alam" \\
"Kecamatan Kota" & "Kaliputu" & "Desa Wisata Kaliputu" & "alam"
\end{tabular}

Gambar 4. Hasil pencarian semua wisata di kudus

2) Tampilkan wisata alam yang ada di Kudus. PREFIX rdf: <http://www.w3.org/1999/02/22-rdf-syntaxns\#> PREFIX owl: <http://www.w3.org/2002/07/owl\#> PREFIX rdfs: <http://www.w3.org/2000/01/rdf-schema\#> PREFIX xsd: <http://www.w3.org/2001/XMLSchema\#> PREFIX data:

<http://www.semanticweb.org/ahmad/ontologies/2021/5/par iwisata5\#>

SELECT ?Kecamatan ?Desa ?Wisata ?Jeniswisata WHERE \{ ?kecamatan data:terdapat ?desa.

?desa data:mempunyai ?wisata.

?kecamatan data:namakecamatan ?Kecamatan.

?desa data:namadesa ?Desa.

?wisata data:namawisata ?Wisata

?wisata data:jeniswisata ?Jeniswisata.

Hasil:

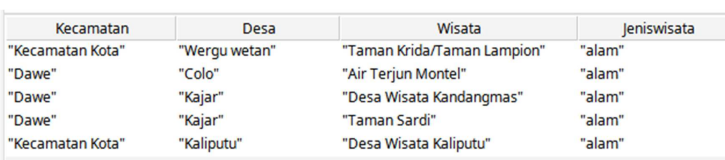

Gambar 5. Hasil pencarian wisata dengan jenis alam

3) Tampilkan wisata religi yang ada di Kudus.

PREFIX rdf: <http://www.w3.org/1999/02/22-rdf-syntaxns\#>

PREFIX owl: 〈http://www.w3.org/2002/07/owl\#> PREFIX rdfs: 〈http://www.w3.org/2000/01/rdf-schema\#> PREFIX xsd: <http://www.w3.org/2001/XMLSchema\#> PREFIX data:

<http://www.semanticweb.org/ahmad/ontologies/2021/5/par iwisata5\#>

SELECT ?Kecamatan ?Desa ?Wisata ?Jeniswisata WHERE \{ ?kecamatan data:terdapat ?desa.

?desa data:mempunyai ?wisata.

?kecamatan data:namakecamatan ?Kecamatan.

?desa data:namadesa ?Desa.

?wisata data:namawisata ?Wisata.

?wisata data:jeniswisata ?Jeniswisata.

Filter regex (?Jeniswisata, "religi","i") \}

Hasil:

\begin{tabular}{l|l|l|l|}
\hline \multicolumn{1}{|c|}{ Kecamatan } & \multicolumn{1}{c}{ Desa } & \multicolumn{1}{c}{ Wisata } & \multicolumn{1}{c}{ Jeniswisata } \\
\hline "Dawe" & "Colo" & "Makam Sunan Muria" & "religi" \\
"Kecamatan Kota" & "Kauman" & "Makam Sunan Kudus" & "Religi" \\
Gambar 6. Hasil pencarian wisata dengan jenis religi
\end{tabular}


4) Tampilkan wisata di kecamatan kota.

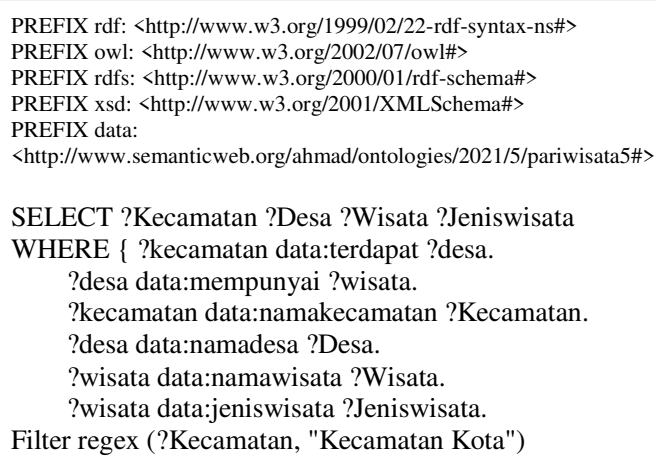

Hasil:

\begin{tabular}{|l|l|l|l|}
\hline \multicolumn{1}{|c|}{ Kecamatan } & \multicolumn{1}{c|}{ Desa } & \multicolumn{1}{c|}{ Wisata } & \multicolumn{1}{c|}{ Jeniswisata } \\
\hline "Kecamatan Kota" & "Wergu wetan" & "Taman Krida/Taman Lampion" & "alam" \\
"Kecamatan Kota" & "Kauman" & "Makam Sunan Kudus" & "Religi" \\
"Kecamatan Kota" & "Kaliputu" & "Desa Wisata Kaliputu" & "alam"
\end{tabular}

Gambar 7. Hasil pencarian wisata di kecamatan kota

\section{5) Tampilkan alamat wisata air terjun montel}

SELECT ?Kecamatan ?Desa ?Wisata ?Jeniswisata WHERE \{ ?kecamatan data:terdapat ?desa.

?desa data:mempunyai ?wisata.

?kecamatan data:namakecamatan ?Kecamatan.

?desa data:namadesa ?Desa.

?wisata data:namawisata ?Wisata.

?wisata data:jeniswisata ?Jeniswisata.

Filter regex (?Wisata, "Air Terjun Montel","i")

Hasil:

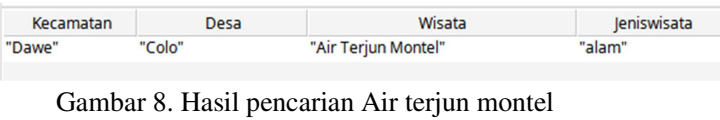

\subsection{Pengujian Ontologi Menggunakan Aplikasi}

Pengujian ontologi ini menggunakan aplikasi sederhana yang dibangun dengan bahasa pemrogaman PHP dan menggunakan RAP (RDF API for PHP) untuk menghubungkan ontologi ke PHP.

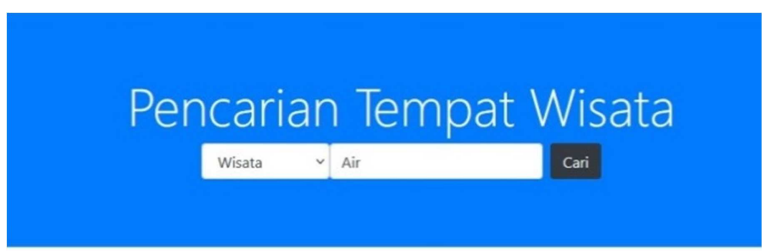

Gambar 9. Aplikasi pencarian wisata untuk menguji ontologi.

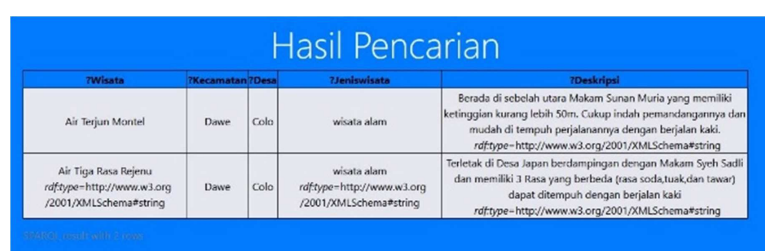

Gambar 10 Hasil pencarian objek wisata alam melalui aplikasi.

Pada gambar 4 dan 5, dilakukan sebuah pengujian pada web browser untuk menguji ontologi. Pengujian tersebut menggunakan kata kunci "Air" untuk wisata yang terdapat kata air pada nama wisatanya. Dari pencarian tersebut terdapat hasil sebanyak 2 tempat wisata.

\section{KESIMPULAN}

Berdasarkan penelitian yang telah dilakukan, diperoleh kesimpulan telah dikembangkan aplikasi sistem pencarian tempat wisata di Kudus dengan menggunakan pendekatan ontologi (semantik web). Informasi tentang tempat wisata disimpan dalam class-class yaitu class wisata dan class lokasi dengan subclass kecamatan dan subclass desa. ontologi yang telah dibangun dapat menampilkan informasi sesuai dengan data-data yang diinginkan seperti lokasi wisata yang meliputi kecamatan dan desa, nama obyek wisata dan jenis wisata yang ada di Kudus.

\section{DAFTAR PUSTAKA}

Arif Rakhman Hakim, 2019. Model Ontologi Varietas Kelapa Sawit Sebagai Dasar Sistem Berbasis Pengetahuan Riset Perkebunan. Jurnal Teknologi Industri Pertanian, 29(2), pp.106-113.

Badron, Yunizar; Agus, Fahrul; Hatta, H.R., 2017. Studi Tentang Pemodelan Ontologi Web Semantik dan Prospek Penerapan pada Bibliografi Artikel Jurnal Ilmiah. Basic Education, [online] 2(1), pp.2338-5081. Available at:

<http://journal.student.uny.ac.id/ojs/ojs/index.php/pg sd/article/viewFile/135/130>.

Baskoro, Y.S., Jayadianti, H., Informatika, J.T., Industri, F.T., Depok, K. and Sleman, K., 2018. Ontologi Pada Domain Kriminalitas Kepolisian. Telematika, 15(01), pp.13-29.

Budihatmojo, H., 2020. Analisis Faktor-Faktor Yang Mempengaruhi. 9, pp.111-118.

Ingan, R., Ginting, C., Herdiani, A. and Darwiyanto, E., 2020. Identifikasi Agenda pada Berita Pilpres 2019 Berbasis Ontologi. 7(1), pp.2399-2408.

Wulandari, I.A., Pahu, G.Y.K.S.S. and Rahayu, P., 2020. Peran Ontologi dalam Pengembangan Sistem Rekomendasi pada Domain Online Learning. Jurnal Komtika (Komputasi dan Informatika), 4(1), pp.1-8. 